\title{
Adventitious root formation in branch cuttings of Taxus wallichiana Zucc.(Himalayan yew): A clonal approach to conserve the scarce resource
}

\author{
Mohd Aslam ${ }^{1 *}$, Parvaiz A. Raina1, Rouf Ur Rafiq ${ }^{2}$, T. O. Siddiqi ${ }^{3}$, Zafar A. Reshi $^{4}$ \\ ${ }^{1}$ Seed Development Division, State Forest Research Institute, Sonwar Bagh, Srinagar, Jammu and Kashmir, India, ${ }^{2}$ School of \\ Studies in Environmental Management, Vikram University, Ujjain, Madhya Pradesh, India, ${ }^{3}$ Department of Botany, Jamia Hamdard, \\ Hamdard University, New Delhi, India, `Department of Botany, University of Kashmir, Srinagar, Jammu and Kashmir, India
}

\author{
Received: 23.03.2017 \\ Accepted: 10.06.2017 \\ Published: 15.06 .2017 \\ *Address for \\ correspondence: \\ Dr. Mohd Aslam Dar, \\ Goripora (Awantipora) \\ Pulwama, Srinagar, \\ Kashmir - 192122 \\ Jammu and Kashmir, India. \\ Phone: +91-9419021436. \\ E-mail: maslamdar@yahoo. \\ co.in
}

\begin{abstract}
Himalayan yew (Taxus wallichiana Zucc.), is an economically valuable plant and critically endangered due to overexploitation for the isolation of Taxol, an exciting anticancer drug from its bark and leaves. Since the species is unisexual and due to its long seed dormancy period and rapid loss of viability coupled with low survival percentage, its natural regeneration from seeds is very poor. As the seed-raised plants add little growth, propagation by stem cuttings was tried under natural conditions and a considerable success was achieved after making use of different auxins (indole-3- acetic acid, indole butyric acid and naphthalene acetic acid) in different concentrations. A randomized block design was adopted for laying the experiment of the present study. Of the 10 treatments studied, IBA at $500 \mathrm{ppm}$ performed best of all the treatments and registered higher callusing percentage, rooting percentage, number of roots, and length of roots in the juvenile shoot cuttings of the species. The results achieved through the application of plant growth regulators by way of adventitious root formation could be useful for the management of this understory coniferous tree species, whether for conservation, habitat restoration, or for the production of Taxol, a promising anticancer agent. The technique evolved will be the most handy, quickest, inexpensive, and can be applied anywhere in its natural habitat for the restoration and restocking of this valuable plant, which is otherwise facing the peril of extinction throughout the range of its distribution including Indian Himalayas.
\end{abstract}

KEY WORDS: Adventitious root formations, conservation, indole butyric acid, medicinal plant, plant growth regulators, propagation, Taxus wallichiana

\section{INTRODUCTION}

Conservation of endangered species and their habitats is a priority feature of environmental policies in many countries and international organizations (Oyonarte et al., 2008). Humans have inflicted so much ecological damage on the planet that a real concern is how to protect what remains (Larsen and Olsen, 2007). Clonal propagation of branch cuttings provides the advantage of greater genetic uniformity and availability of superior stock in a short period for afforestation works. It also permits the multiplication of a desired tree having superior characters (otherwise called as candidate plus tree). The resulting populations of plants have the same genotype as the original source (ortet) and are called the clone (ramet)
(Saini, 1998). It is considered as the only preferred practicable option for the cultivation of a species on large scale with better quality and higher yield, thereby augmenting forest productivity (Aslam and Rather, 2008). Adventitious root formation (ARF) has been successfully used in a program of conservation of genetic resources of some medicinal woody plants in Nigeria (Oni, 1993). The vibrant but fragile forest ecosystems of the Kashmir Himalaya also warrants the development of economical and time-saving means for the proliferation of superior clonal stock (Aslam, 2007). An efficient rooting treatment can lead to a high percentage of rooting and a higher quality of root system (De Klerk et al., 1997). Quality involves root number and length, both of which influence the performances of the plants after transfer to field 
(Mohammed and Vidaver, 1990). Many factors, during the rooting phase, can cause poor quality of the shoots at the time of planting (Hartmann et al., 2002). To cater to such needs the plant growth regulators (PGRs) have long been recognized as great fillip (Nanda, 1970; Blazich, 1988; Davis and Haissig, 1990; Nanda and Kochhar, 1995).

The Taxus wallichiana Zuccarini (syn. Taxus baccata subspecies wallichiana (Zucc. Piger), commonly known as Himalayan yew belongs to family Taxaceae, is an understory temperate gymnosperm of high medicinal value and ethnobotanical importance. Although the members of this family are apparently similar to the conifers, due to the absence of cones and resin ducts, are placed in a separate order named as Taxales. It has been in frontline focus, as a terrible fate befell on this conifer more recently because of its overexploitation and excessive destructive harvesting from its natural stands (Aslam et al., 2009). Consequently, the species has to bear the brunt of excessive clipping of foliage and bark removal, as a prime source of various taxoids presented as a highly effective anticancerious drugs (CITES, 2009). It is originally, the Pacific yew (Taxus brevifolia), which has entered the halls of fame, because research into its chemistry resulted in the discovery of a well-known anticancer drug, Taxol (Stephen, 1991). Subsequently, the taxol and related bioactive taxoids have been reported from the various species of the genus, including T. wallichiana (Bala et al., 1999; Prasain et al., 2001; and Wani et al., 1971). As such, the large-scale foliage and bark collection would definitely do more harm than good and could hence erode the very genetic resource base of the species. Since the occurrence of the species has reduced to a great extent and is on its fade out; a conservative approach is required to protect this scarce resource globally.

Taxus is genus of 10 species and taxonomically regarded as the troublesome genus because of the variability and overlapping nature of the limited number of morphological features that are used to distinguish the species (Edward, 1998). Classically, the 10 renowned species of genus Taxus are T. baccata (European yew or English yew), T. brevifolia (Nor thwest Pacific yew), Taxus canadensis (Canadian yew), Taxus chinensis (Chinese yew), Taxus cuspidata (Japanese yew), Taxus floridana (Florida yew), Taxus sumatrana (Sumatran yew), Taxus globosa (Mexican yew), Taxus celebica (Celebes yew), and T. wallichiana (Himalayan yew) (Paul et al., 2013). The range of T. wallichiana comprises Afghanistan, Bhutan, China, India, Pakistan, Indonesia, Malaysia, Myanmar, Nepal, Vietnam, and the Philippines (Riedl, 1965). In the Indian Himalayas, the species occurs in the Northern-Western States of Jammu and Kashmir,
Himachal Pradesh, Uttarakhand, Sikkim, Assam, and Arunachal Pradesh at altitudes between 1800 and 3300 m (amsl) and in the hills of Meghalaya and Manipur at an altitude of $1500 \mathrm{~m}$ (amsl) (Karki and Gupta, 2000; Sahni, 1990). In Kashmir Himalaya, the species shows its prevalence more in Gulmarg, Baramulla, and Pahalgam regions and also grows extensively in the inner areas of Vaastoorwon forests at Tral, of Awantipora Forest Division (Aslam, 2014). Likewise, the species also grows in Sudhmahandev, Patnitop, Sannasar, Sarthal, and Dudu Basantgarh areas of Jammu Province (Sharma, 2014). The Himalayan yew's habitat is mostly characterized by mixed coniferous forest species (Abies pindrow, Abies spectabilis, Cedrus deodara, Pinus wallichiana, and Picea smithiana) or broadleaf tree species (Prunus padus, Quercus semicarpifolia, Aesculus indica, Betula utilis, Acer caesium, Rhododendron arboretum, and Juglans regia) (Aslam et al., 2009) and grows as scattered individuals and small groups of trees on or near streams banks and river margins, canyon bottoms, and wet-shaded ravines and in other moist habitats (Crawford and Johnson, 1985).

The extracts of $T$. wallichiana are known to be a source of a drug, called Zarnab, which is very frequently prescribed in the Unani System of Indian Medicine as sedative, and for the treatment of bronchitis, asthma, snake bites, epilepsy, scorpion stings, diarrhoea, severe biliousness, giddiness, feeble, and falling pulse, besides application as an aphrodisiac (Anonymous, 1976; Mulliken and Crofton, 2008). The leaves of this plant are also credited with antispasmodic properties and are employed for the treatment of hysteria, nervousness, carminative, and antimalaria properties (Chauhan, 1999). Before independence in Jammu and Kashmir, especially in Ladakh, Taxus bark was used as a substitute for preparing herbal teas locally known as "Namkeen Chai" and frequently used for curing coldness of extremities (Aslam, 2006). The pulp of fleshy bright-scarlet aril is gelatinous and very sweet tasting and is used in jams, ice creams, as long as the toxic seed is removed and can also be added in cosmetics, such as hair lotions, rinses, beauty and shaving creams, and dentifrices (Aslam et al., 2009; Edward, 1998). The arils, removed from the seeds, have diuretic and laxative effects (Orwa et al., 2009). The wood of Taxus is considered as the hardest of all coniferous woods and is valued for its strength, durability, and decorative character (Sabina, 2006). It is also highly resistant to rot and insect attack and can be worked, polished, and stained excellently (Dar and Dar, 2006). The colorful wood (red heartwood and white sapwood), is used for cabinet work, candle sticks, and other fancy articles, such as handles of knives, doors, and back of combs. It is used for furniture, veneers, 
parquet flooring, and paneling and for gates, fences, pegs, and various art objects (Oldfield et al., 1998). In J\&K, the fine-grained elastic wood was formerly valued for making archery bows and fine musical instruments (Aslam et al., 2004; Vance and Rudolf, 1974). It is also used for making ploughs, carts, axles, spindles, and also for the construction of beehives (Purohit et al., 2001). It is used as a cheaper type of gun and rifle wood (Troup, 1921). The wood is also used in the cremation of dead bodies and its bark also finds use in making essence sticks (Aslam, 2006; Gamble, 1922). As the poisonous contents are usually low in the tree, its foliage is also used under extreme conditions (particularly in winter and early spring) as cattle fodder, when the snow reduce access to grazing (Aslam, 2016). Ironically, it is not for the timber but for the leaves and bark for which the anticancer yew trees are in the threat of extinction.

The importance of the tree has further increased in the recent times with the yield of Taxol, which is extracted from its bark and leaves, and demonstrated broad antitumor activity against the breast, liver, lung, blood, prostrate, head and neck, gynecological cancers, and Kaposi's sarcoma - an AIDS-related cancer (Cragg et al., 1993; Donehower and Rowinsky, 1993). In addition, taxol may prove useful against other non-cancer disorders including polycystic kidneys diseases (Woo et al., 1994). It was first commercially developed by the pharmaceutical company Bristol-Myers Squibb Company-Princeton, NJ with the generic name paclitaxel and sold under the trademark Taxol (McCoy, 2004; Wheeler and Hehnen, 1993). Taxotere is a registered trademark of RhonePoulenc Sante-Paris, France. Its generic name is Docetaxel. At best, $1 \mathrm{~kg}$ of dried yew bark yields only $50-150 \mathrm{mg}$ of pure Taxol and for producing a gram of the substance three trees each at least 60 years are required and $1 \mathrm{mg}$ of it costs $\$ 60$ in the world market (Stephen, 1991), such a high monetary incentives have lead to reckless exploitation and an immediate threat to the prosperity of this precious plant. Even though severe restrictions have been imposed by the State Forest Departments on the removal of Taxus trees from the forest areas, illegal debarking, removal of shoots, and even tree continues unabated. This clandestine trade has wiped out yew trees from the whole forests of Jammu and Kashmir State and elsewhere (Aslam et al., 2004). Owing to these reasons, $T$. wallichiana was listed in Appendix 2 CITES (Thomas and Farjon, 2011) in 1995. It was assessed as data deficient (DD) by IUCN in 2006 (Paul et al., 2013).

The conservation situation of T. wallichiana is becoming worsening due to the destruction of its natural habitat and collection of its leaves and bark for medicines since 1970s, the distribution of this species have been progressively reduced (Fu, 1991). Conservation of this endangered species and its habitats are becoming urgent and basic studies are needed for it. Any contribution to restore the population of threatened species is a milestone to conserve valuable species for the greater benefits of humankind. Although the regeneration of Taxus through seeds is possible (Pandey et al., 2002), but faces constraints mainly because of slow process, rapid loss of seed viability coupled with low survival percentage (Rajewski et al., 2000). So as to counter its continuous degradation and to augment its natural regeneration and large scale cultivation, attempts for its artificial regeneration are urgently called for. Since T. wallichiana is shy to root (Aslam, 2006), vegetative propagation through cuttings, was attempted by the State Forest Research Institute-J\&K, (India) after treated with PGRs of different concentrations in the natural conditions within its original climatic zone. The use of PGRs to induce adventitious rooting in branch cuttings of most forest tree species is well known (Husen and Pal, 2006), and could be a feasible way to achieve conservation and restoration goals as well as to meet the demand for paclitaxel (Heinstein and Chang, 1994), for which the species is facing the peril of extinction (Aslam, 2016).

However, a well-documented scientific study in this species with regard to efficient hormonal treatment and exact concentration is fragmentary/missing. Keeping in view the small population size, poor regeneration, slow propagation, habitat specificity, destructive harvesting, overgrazing, high value of utilization, and habitat loss, the present study was planned to raise adequate supply of clonal stock through adventitious rooting with desirable traits, so as to achieve suitable propagation protocol for this under pressed species, for use in field for the propagators of Jammu and Kashmir State and elsewhere.

\section{MATERIALS AND METHODS}

\section{Experimental Site}

The experiment has been carried out at the Forest Research Center, Seer of State Forest Research Institute (SFRI), Jammu and Kashmir, India, which is situated about $2.5 \mathrm{~km}$ from Seer village on Khanabal-PahalgamShri Amarnathji cave road and $12 \mathrm{~km}$ from main Anantnag town. The nursery is located in compartment no.03/Lidder Forest Division at an elevation of 1,900 m above mean sea level (amsl) on the Western aspect and lies at $34^{\circ}-17^{\prime} \mathrm{N}$ latitude $75^{\circ}-20^{\prime}$ E longitude, receiving mean rainfall of $2012.7 \mathrm{~mm}$ annually. Severe frost and 
snowfall is a usual feature in this area from December to February and hence experiences a wide range of monthly temperature variations ranging from $-5.0^{\circ} \mathrm{C}$ (January) to $35.3^{\circ} \mathrm{C}$ (June).

\section{Collection and Preparation of Cuttings}

The trees of $T$. wallichiana growing in the compartment37/L in Pahalgam range of Lidder Forest Division were sheared by removing their juvenile apical shoots and brought to the experimental site in clean and moistened gunny bags to avoid them from desiccation $\left(3^{\text {rd }}\right.$ week of March, 2008). Subsequently, the cuttings of uniform size (22 cm length $\times 0.5-1.0 \mathrm{~cm}$ diameter) were then prepared from these excised shoots. Needles from the 5 to $8 \mathrm{~cm}$ basal portion of these cuttings were removed carefully, while sufficient number of leaves at the upper portion was kept intact.

\section{Treatments of Cuttings}

The basis of each cuttings was given slanting cut and dipped in $0.1 \%$ aqueous solution of Bavistan containing $50 \%$ carbandizam w/w (fungicide-BASF India Ltd.) for 3-5 min to protect cuttings from any chances of fungal infection, subsequently washed with distilled water. These cuttings were subjected to 9 treatments, that is, 3 phytohormones, namely, indole-3-acetic acid (IAA), indole butyric acid (IBA), and naphthalene acetic acid (NAA) (Sigma Chemicals Co., St. Louis, USA) each with three concentrations, namely, IAA, (IAA $500 \mathrm{ppm}$, $1000 \mathrm{ppm}$, and $2000 \mathrm{ppm}$ ), IBA (IBA 500 ppm, 1000 ppm, and $2000 \mathrm{ppm}$ ), and NAA (NAA 500 ppm, $1000 \mathrm{ppm}$, and 2000 ppm) (Table 1). Before planting, the lower portions of these juvenile cuttings were dipped separately in the appropriate hormonal solutions for $24 \mathrm{~h}$. The cuttings treated with distilled water served as control. Three replicates each of thirty cuttings were maintained for each treatment. The selection of rooting hormone, their concentration, and duration of the treatment was based on the rooting response of the cuttings in our earlier experiments with the species. All the chemicals were first dissolved in $10 \mathrm{ml}$ of ethanol and then making the final volume to $1 \mathrm{l}$ by adding double distilled water.

\section{Propagation Medium and Planting of Cuttings}

Immediately following the chemical treatments, cuttings were planted to about 5-6 cm depth, maintaining uniformity, in the perforated polybags (size $20 \times 10 \mathrm{~cm}$ ) filled with forest soil, sand, and humus $(2: 1: 1)$, firmed to position, and permitted to develop adventitious roots. The polybags were arranged in a randomized block design under the shade of $P$. wallichiana trees in natural conditions (Figure 1a-c) and watered manually with the help of rose cane on alternate days depending on the weather conditions and rooting medium moisture status without disturbing the experiment. The polybags were kept free of weeds manually.

\section{Recording of Data on Adventitious Rooting in Cuttings}

The data on various rooting parameters were recorded by observing cuttings from each replicate of each treatment after 5 weeks of treatment. The final observation on callusing, root emergence, number of roots emerged, and length of roots emerged were recorded after 18 weeks, when the experiment was terminated. All the cuttings with even 1 callus were considered as callused and used for calculating callusing percentage. Cuttings with roots $\geq 1 \mathrm{~mm}$ roots were considered to have rooted and used for calculating rooting percent and accordingly root/roots $>2 \mathrm{~mm}$ were considered for calculating mean root number and mean root length per cutting.

Table 1: Effect of auxins on induction and growth of adventitious roots in shoot cuttings of Taxus wallichiana after 18 weeks of treatment and planting. Results are the mean values of three replicates

\begin{tabular}{lcccc}
\hline Treatment $(\mathrm{ppm})$ & Callusing $(\%)$ & Rooting $^{2}(\%)$ & Roots per cutting $^{3}\left(\mathrm{mean}^{4} \pm \mathrm{SE}^{5}\right)$ & Root length per cutting $^{3}\left(\mathrm{mean}^{4} \pm \mathrm{SE}^{5}\right)$ \\
\hline $\mathrm{T}_{1}$ Control & 4.30 & 8.00 & $3.60 \pm 0.14$ & $3.20 \pm 0.15$ \\
(untreated) & & & & \\
$\mathrm{T}_{2}$ IAA 500 & 6.67 & 40.00 & $10.21 \pm 0.38$ & $8.40 \pm 0.14$ \\
$\mathrm{~T}_{3}$ IAA 1000 & 6.00 & 30.00 & $11.00 \pm 0.17$ & $11.83 \pm 0.28$ \\
$\mathrm{~T}_{4}$ IAA 2000 & 4.30 & 15.00 & $6.00 \pm 2.06$ & $7.20 \pm 0.29$ \\
$\mathrm{~T}_{5}$ IBA 500 & 11.3 & 76.66 & $12.33 \pm 0.66$ & $12.50 \pm 0.21$ \\
$\mathrm{~T}_{6}$ IBA 1000 & 4.58 & 30.00 & $5.65 \pm 0.29$ & $9.50 \pm 0.69$ \\
$\mathrm{~T}_{7}$ IBA 2000 & 3.55 & 20.00 & $3.20 \pm 0.23$ & $6.80 \pm 0.24$ \\
$\mathrm{~T}_{8}$ NAA 500 & 8.20 & 70.30 & $11.20 \pm 0.24$ & $11.95 \pm 0.28$ \\
$\mathrm{~T}_{9}$ NAA 1000 & 4.23 & 30.00 & $4.20 \pm 0.12$ & $9.10 \pm 0.29$ \\
$\mathrm{~T}_{10}$ NAA 2000 & 3.30 & 25.00 & $6.30 \pm 0.14$ & $8.70 \pm 0.27$ \\
CD at P=0.05\% & 1.893 & 27.006 & 1.029 & 1.155 \\
\hline
\end{tabular}

Mean values are significantly different at $P=0.05 \%$. ${ }^{1}$ Cuttings with even 1 callus were considered as callused, ${ }^{2}$ Cuttings with roots $\geq 1 \mathrm{~mm}$ roots were considered to have rooted, ${ }^{3}$ Root/roots $>2 \mathrm{~mm}$ were considered for calculating mean root number and mean root length per cutting, ${ }^{4} \mathrm{Mean}$ : Mean values of the three replicates in each treatment, ${ }^{5} \mathrm{SE}$ : Standard error of the mean 


\section{Statistical Analysis}

Data were subjected to analysis of variance (ANOVA) and F-tests for significance as per the procedure devised by Panse and Sukhatme, 1967. Critical difference values were calculated for comparing the treatment means at $P=0.05$.

\section{RESULTS AND DISCUSSION}

The data with regard to effect of auxins on induction and growth of adventitious roots in shoot cuttings of T. wallichiana after 18 weeks of treatment and planting are depicted in Tables 1 and 2. A look on the data recorded in the present study clearly reveals that the auxins, in general, proved effective on root induction and growth of adventitious roots in stem cuttings of T. wallichiana within 18 weeks of treatment and planting (Table 1). In general, it has been observed that among all the three auxins (IAA, IBA, and NAA) tried, treatment $\mathrm{T}_{5}$ (IBA at $500 \mathrm{ppm}$ ) was the most effective for root induction. Lower concentrations (500 ppm) of all the three auxins were found to be better than higher concentrations. The lower concentrations, i.e., IBA 500 ppm, IAA 500 ppm, and NAA 500 ppm tried also showed maximum callusing percentage, rooting percentage, roots per cutting, and

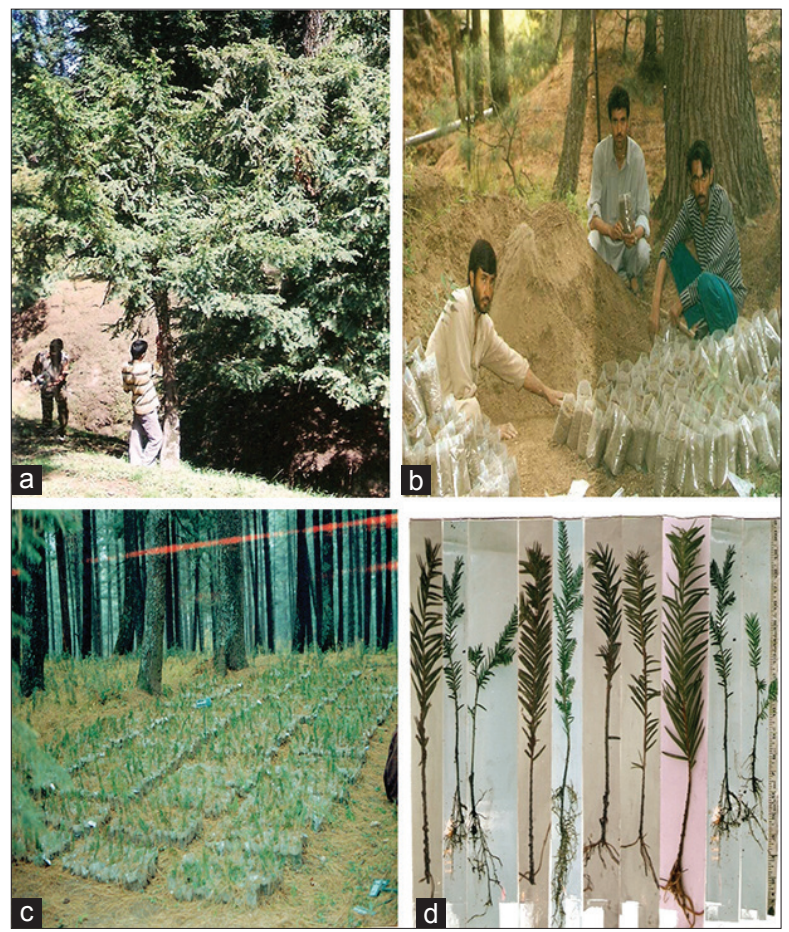

Figure 1: Conserving the scarce resource of Taxus wallichiana in Kashmir Himalaya (J\&K), India. (a) A medium-sized and densely branched tree of yew, (b) preparation of rooting medium and filling of polybags (author in middle of photo), (c) cuttings planted in polybags for the stimulation of rooting, and (d) representative rooting response of yew cuttings after treated with various plant growth regulators after the 18 weeks of treatment and planting root length per cutting except in IAA 500 ppm where maximum root length per cutting was observed in IAA $1000 \mathrm{ppm}$. The highest rooting of $76.66 \%$ was recorded under IBA $500 \mathrm{ppm}$ with 12.33 roots per cutting attaining about $12.50 \mathrm{~cm}$ root length. This was closely followed by NAA $500 \mathrm{ppm}$ where a rooting of $70.30 \%$ was achieved with 11.20 roots per cutting attaining about $11.95 \mathrm{~cm}$ root length. However, control cuttings (untreated) were observed to have lowest callusing percentage $(4.30 \%)$, rooting percentage $(8.00 \%)$, and accordingly root number and root length per cutting.

The ANOVA is presented in Table 2, which clearly shows that all the treatments differed significantly with respect to all the rooting parameters, namely, callusing, rooting, roots per cutting, and root length per cutting. It therefore revealed that treatment $\mathrm{T}_{5}$ (IBA at $500 \mathrm{ppm}$ ) is the best and most efficient hormone and concentration in stimulation of callusing, rooting, higher root number, and greater length of primary roots in the juvenile branch cuttings of T. wallichiana (Table 1 and Figure 1a-d). The rooting was very slow and not profuse with $\mathrm{T}_{1}$ (control). Hence, to induce profuse rooting, treatment of cuttings with the auxins in general and IBA at $500 \mathrm{ppm}$ in particular is found to be beneficial.

A varying degree of success on the rooting with auxins in juvenile shoot cuttings of $T$. wallichiana has been reported from other temperate regions of the country as well (Dubey, 1997; Khali and Sharma, 2003; Mishra et al., 2000; Mitter and Sharma, 1999; and Nandi et al.,1997). Aslam and Rather, 2008 reported that among all the auxins tried, IBA is the most effective hormone for the induction of higher percentage of rooting in the juvenile cuttings of T. wallichiana. Similar results have been found using IBA with a number of other yew cultivars (Eccher, 1988; van Hofi, 1978; and von Korya, 1976) and indicated that hormone treatment was important for a successful propagation and conservation program. These results are also in line with Nautiyal et al. (1991), who used

Table 2: ANOVA on effect of auxins on induction and growth of adventitious roots in shoot cuttings of Taxus wallichiana after 18 weeks of treatment and planting

\begin{tabular}{lcccc}
\hline Source of variation & \multicolumn{3}{c}{ MSS } & F-value \\
\cline { 2 - 4 } & Treatment & Replication & Error \\
\hline Degree of freedom(df) & 9 & 2 & 18 \\
Callusing & 17.46 & 1.05 & 1.22 & $14.31^{*}$ \\
Rooting & 652.91 & 207.53 & 248.45 & $2.62^{*}$ \\
Roots per cutting & 36.2 & 0.02 & 0.37 & $97.83^{*}$ \\
Root length per cutting & 23.53 & 0.48 & 0.46 & $51.15^{*}$ \\
\hline
\end{tabular}

MSS: Mean sum of square, *highly significant at $0.05 \%$ level of significance, ANOVA: Analysis of variance 
auxins in inducing rooting on branch cuttings of teak and concluded that IBA is the best auxin. Some other researchers (Aslam et al., 2007; Blazich, 1988; Chandra and Verma, 1989; Gurumurti and Bhandari, 1988; Nautiyal et al., 2004; Pal, 1992; and Singh and Chander, 2001) also reported that exogenous application of IBA and other auxins in promotion of ARF in stem cuttings of many plants including Taxus. It is a well-established fact that the application of auxins is necessary for the formation of roots in stem cuttings as they have been found to stimulate cambial activity thereby resulting the mobilization of reserve food material to the site of root initiation (Haissig, 1974; Philips, 1971). Applications of auxins enhanced rooting and root quality in many tree species (Hartman and Kester, 1983). The application of IBA may have an indirect influence by enhancing the speed of translocation and movement of sugar to the base of cuttings and consequently stimulate rooting (Haissig, 1974). It has also been suggested that optimum concentration of auxins is favorable, whereas concentration above optimum is toxic to the root regeneration (Avanzato et al., 1998; Chauhan and Reddy, 1974). The higher concentration of all the three auxins IAA, IBA, and NAA had been less effective than lower one for various rooting attributes (Tables 1 and 2 Figure 1a) could be due to similar actions in T. wallichiana in the present investigation as well.

Growth regulators (auxins) are involved in plant root formation, lateral bud inhibition, and activation of cambial cells. They have been identified as naturally occurring compounds promoting root formation and synthetic auxins also practically stimulating root formation on cuttings. It is well accepted and confirmed many times that auxins naturally or ar tificially applied are required for the initiation of adventitious roots on stem cuttings. Division of root initial cells is dependent on either applied or endogenous auxins (Gill et al., 2006) and leads to synthesis of root primordial (Nanda, 1970). The leaves present in cuttings supply necessary root-promoting substances (Hartmann et al., 1981; Nanda and Kochhar, 1995; and Pant and Joshi, 1999) probably by performing photosynthesis during propagation (Mesen et al., 1997; Pant and Joshi, 1999), as is the case in the present study, in which a good number of leaves on the upper portion of the cuttings were kept intact. In the cuttings, where there was no root formation or it was delayed, the survival becomes very difficult or the cutting was likely to die (Dugma, 1988; Puri andThompson, 1989).

\section{CONCLUSION}

Since IBA $500 \mathrm{ppm}$ treatment is proven to be the best rooting hormone and concentration for rooting of juvenile shoot cuttings of $T$. wallichiana. Therefore, it is recommended that this threatened, fragile, and overexploited medicinally important plant species be preserved to the greatest extent possible for the future generations with the aid of auxins in general and IBA at $500 \mathrm{ppm}$ in particular. Keeping in view the development of present technique along with the status, importance, and conservation value of T. wallichiana, well-rooted plants could be obtained within a short time; the method is also inexpensive and easy to perform under natural conditions. Such knowledge will aid propagators, geneticists, and tree improvement specialists in selecting treatments that reduce propagation cost by maximizing rooting success. This will in turn help to enhance resource availability for meeting the market demand of the species for the extraction of Taxol, for which the species is exploited recklessly. Hopefully, the present studies will also pave the way to enhance the quality and productivity of forest ecosystems of the Kashmir Himalaya and to compensate the damage caused to this exciting tree species which has included it in the 2000 IUCN Red List.

\section{ACKNOWLEDGMENT}

The authors are thankful to The Director, State Forest Research Institute, J\&K, for providing valuable suggestions and necessary facilities for conducting the study. Mention is also merited to the staff of Forest Research Center, Seer of SFRI, J\&K, for their generous assistance in performing the experiment. The first author (MA) availed Research Fellowship on ICFRE-WB funded RGF project no.405/97-ICFRE (R) entitled, "Coordinated research project on improvement of $P$. wallichiana" in State Forest Research Institute, J\&K, which is gratefully acknowledged.

\section{REFERENCES}

Anonymous. The wealth of India-a dictionary of Indian raw materials and industrial products. Publication and Information Directorate. Vol. X. New Delhi, India: Council of Scientific and Industrial Research; 1976. p. 591.

Aslam M, Ali M, Reshi ZA, Siddiqi TO. Status of Himalayan yew (Taxus baccata Linn.) in a mixed coniferous forest of the Kashmir Himalaya. Natl J Life Sci 2009;6:55-61.

Aslam M, Arshid S, Rather MS, Salathia HS, Seth CM. Auxin induced rooting in Taxus baccata Linn. Stem cuttings. Indian J Forstery 2007;30:221-6.

Aslam M, Rather MS. Macro-propagation of Taxus baccata Linn.: A novel method for conserving a critically endangered medicinal plant. Indian Forester 2008;134:1058-66.

Aslam M, Tariq S, Wadoo MS. Taxus baccata Linn. (Himalayan yew): A versatile Himalayan asset. In: Wadoo MS, edition. 
Vanaspaties in the Service of Human Kind. Srinagar, Kashmir-J\&K: Idris Publications; 2004. p. 324-34.

Aslam M. Himalayan Yew Faces Extinction. Sunday Magazine Excelsior, February 5; 2006.

Aslam M. Himalayan Yew, Taxus wallichiana: An Exciting Conifer with an Uncertain Future. New Delhi, India: Accepted by Science Reporter, CSIR-NISCAIR; 2016.

Aslam M. Himalayan Yew: A Vanishing Wonder Tree. Rising Kashmir, June 25; 2014.

Avanzato DG, Couvillon A, Pokomy FA. The influence of p-IIB (Phenyl indole 3 thiolobutyrate), Aryl ester of IBA, on the rooting of Red haven peach. Acta Hortic 1998;227:197-201.

Bala S, Uniyal GC, Chattopadhyay SK, Tripathi V, Sashidhara KV, Kulshrestha M, et al. Analysis of taxol and major taxoids in Himalayan yew, Taxus wallichiana. J Chromatogr A 1999;858:239-44.

Blazich FA. Chemicals and formulations used to promote adventitious rooting. In: Davis TD, Haissig BE, Sankhla N, editors. Adventitious Root Formation in Cuttings. Portland, USA: Dioscorides Press; 1988. p. 132-49.

Chandra JP, Verma SD. Root ability of softwood cuttings of individual mother tree of eucalyptus. Proceeding Seminar on Vegetative Propagation, Held at Coimbatore, India, 27 to 28 July; 1989.

Chauhan KS, Reddy TS. Effect of growth regulators and mist on rooting in stem cuttings of plum. Indian J Hortic 1974;32:229-31.

Chauhan NS. Medicinal and Aromatic Plants of Himachal Pradesh. $1^{\text {st }}$ ed. New Delhi: Indus Publishing Company New Delhi, India; 1999. p. 401-3.

CITES-Convention on International Trade in Endangered Species of Wild Fauna and Flora. Appendices I, II, and III. Available from: http: / / www.cites.org. [Last accessed 2010 Oct 20].

Cragg GM, Schepartz SA, Suffness M, Grever MR. The taxol supply crisis. New NCI policies for handling the large-scale production of novel natural product anticancer and antiHIV agents. J Nat Prod 1993;56:1657-68.

Crawford RC, Johnson FD. Pacific yew dominance in tall forests, a classification dilemma. Can J Bot 1985;63:592-602.

Dar AR, Dar GH. The wealth of Kashmir Himalayagymnosperms. Asian J Plant Sci 2006;5:251-9.

Davis TD, Haissig BE. Chemical control of adventitious root formation in cuttings. Plant Growth Regul Soc Am Q 1990;18:1-8.

De Klerk GJ, Ter Brugge J, Marinova S. Effectiveness of indoleacetic acid, indolebutyric acid and naphthalene acetic acid during adventitious root formation in vitro in Malus 'Jork9'. Plant Cell Tissue Organ Cult 1997;49:44.

Donehower RC, Rowinsky EK. An overview of experience with TAXOL (paclitaxel) in the U.S.A. Cancer Treat Rev 1993;19 Suppl C:63-78.

Dubey KP. Himalayan yew (Taxus baccata) conservation: A vegetative approach. Indian Forestery 1997;123:1150-4.

Dugma B. Establishment of stakes of Gliricidia sepium and Leuceana leucocephala. Nitrogen Fifing Res Rep 1998;6:6-9.

Eccher T. Response of cuttings of 16 cultivars to rooting treatments. Acta Hortic 1988;227:251-3.

Edward EA. Taxaceae: The Genera and cultivated species. In: Bailey LH, editor. The Botanical Review. Vol. 64. New York: Hortorium Cornell University Ithaca; 1998.

Fu LG. The Red Book of Plants of China. Beijing: Science Press; 1991.

Gamble JS. A Manual of Indian Timbers. London: Simpson Low, Maston \& Company Limited; 1922. p. 868.

Gill MK, Chauhan SK, Gossal SS. Macro-and Micro-propagation of Azadirachta indica. Indian Forestry 2006;132:1159-66.

Gurumurti K, Bhandari HC. Induction of rooting in cladode cuttings of Casuarina equistifolia. Curr Sci 1988;57:1-2.

Haissig BE. Influences of auxin synergists on adventitious root primordium initiation and development. NZ J Forestty Science 1974;4:311-23.

Haissig BE. Metabolism during adventitious root primordium initiation and development. $\mathrm{N}$ Z J Forestry Sci 1974;4:324-37.

Hartman HT, Kester DE. Plant Propagation: Principles and Practices. USAS: Prentice Hall, Englewood Cliffs; 1983. p. 662.

Hartmann HT, Folker WJ, Kofranesl AM. Plant Science: Growth, Development and Utilization of Cultivated Plants. USA: Prentice-Hall Inc. Englewood Cliffs; 1981.p. 89-96.

Hartmann HT, Kester DE, Davis FT Jr, Geneve RL. Plant Propagation: Principles and Practices. $7^{\text {th }}$ ed. USA: Prentice-Hall, Inc Englewood Cliffs; 2002.

Heinstein PF, Chang CJ. Taxol Annu Rev Plant Physiol Plant Mol Biol 1994;45:663-74.

Husen A, Pal M.Variation in shoot anatomy and rooting behavior of stem cuttings in relation to age of donor plants in teak (Tectona grandis Linn.). New Forestry 2006;31:57-73.

Karki MM, Gupta VK. Natural product innovations: Taxol. J Intellect Prop Rights 2000;5:206-10.

Khali RP, Sharma AK. Effect of phytohormones on propagation of Himalayan yew (Taxus baccata Linn.) through stem cuttings. Indian Forestry 2003;129:289-94.

Larsen $\mathrm{HO}$, Olsen CS. Unsustainable collection and unfair trade? Uncovering and assessing assumptions regarding Central Himalayan medicinal plant conservation. Biodivers Conserv 2007;16:1679-97.

McCoy M. Lining up to make a cancer drug. Chem Eng News 2004;82:12-4.

Mesen FA, Newton C, Leakey RR. Vegetative propagation of 
Cordia alliodora (Ruiz and Pavon) Oken. Forest Ecol Manag 1997;92:45-54.

Mishra A, Singh A, Kukreja AK, Patra NK. Adventitious root induction in stem cuttings of Taxus baccata Linn. For ex-situ cultivation. J Non Wood Forestry Prod 2000;12:63-6.

Mitter H, Sharma A. Propagation of Taxus baccata Linn. By stem cuttings. Indian Forester 1999;125:159-62.

Mohammed GH, Vidaver WE. The influence of acclimatization treatment and plantlet morphology on early greenhouse performance of tissue-cultured Douglas fir (Pseudotsuga menziesii) Mirb Franco. Plant Cell Tissue Organ Cult 1990;21:111-7.

Mulliken T, Crofton P. Review of the status, harvest, trade, and management of seven Asian CITIES-listed medicinal and aromatic plant species Bonn: BFN-Skripten. Fed Agency Nat Conv 2008; 115-6.

Nanda KK, Kochhar VK. Vegetative Propagation of Plants. New Delhi: Kalyani Publishers; 1995.

Nanda KK. Investigation on the Use of Auxins in Vegetative Reproduction of Forest Plants. Final Report PL 480 Research Project; 1970. p. 215.

Nandi SK, Rikhari HC, Nadeem M, Palni LM. Clonal propagation of Taxus baccata Linn. Himalayan asset under threat. Physiol Mol Biol Plants 1997;3:15-24.

Nautiyal S, Dhyani M, Kumar P, Bhandari HC. Rooting response of juvenile shoot cuttings of Terminalia arjuna under different hormonal treatment. National Workshop on Potential and Strategies for Sustainable Development of Vanya Silks in the Himalayan States; 2004. p. 70-4.

Nautiyal S, Singh U, Gurumurti K. Rooting response of branch cuttings of Teak (Tectona grandis) as influenced by season and growth hormones. Indian Forester 1991;125:249-55.

Oldfield S, Lusty C, Mackinven A. The World List of Threatened Trees. UK: World Conservation Press Cambridge; 1998. p. 650 .

Oni O. Conservation and vegetative propagation of the genetic resources of some endangered medicinal woody plants of Nigeria. Acta Hortic 1993;331:269-74.

Orwa C, Mutua A, Kindt R, Jamnadass R, Simons A.Agroforestry Database: A Tree Reference and Selection Guide; 2009. Available from: http: / /www.worldagroforestry.org/af/ treedb. [Last accessed on 2016 Sep 06].

Oyonarte C, Aranda V, Durante P. Soil surface properties in Mediterranean mountain ecosystems: Effects of environmental factors and implications of management. Forest Ecol Manag 2008;254:156-65.

$\mathrm{Pal}$ M. Clonal propagation for yield improvement in forest plantations. IPPTA 1992;4:151-8.

Pandey A, Nadeem M, Palni LM. Improvement in seed germination of Himalayan yew through simple soil treatments. Indian J Forest 2008;25:109-13.
Panse VG, Sukhatme PV. Statistical Methods for Agriculture Workers. New Delhi: ICAR; 1967. p. 610.

Pant KK, Joshi SD. Ex-situ Propagation and Conservation of Taxus baccata L. And Podocarpus neriiflolus D. Don. Proceedings II RONAST; 1999.

Paul A, Bharali B, Mohamed LK, Omprakash T. Anthropogenic disturbances led to risk of extinction of Taxus wallichiana zuccarini, an endangered medicinal tree in Arunachal Himalaya. Nat Areas J 2013;33:447-54.

Philips ID. Introduction to the Biochemistry and Physiology of PG Hormones. New York, USA: McGraw-Hill Book Company; 1971.

Prasain JK, Stefanowicz P, KiyotaT, Habeichi F, Konishi Y.Taxines from the needles of Taxus wallichiana. Phytochemistry 2001;58:1167-70.

Puri S, Thompson FB. Rooting of stem cuttings of Populus $\times$ euramericana under different water potentials. Ann Sci Forest 1989;46:1275-95.

Purohit A, Maikhuri RK, Rao KS, Nautiyal S. Impact of bark removal on survival of Taxus baccata L. (Himalayan yew) in Nanda Devi biosphere reserve, Garhwal Himalaya, India. Curr Sci 2001;81:586-90.

Rajewski M, Lange S, Hattemer HH. Problems of reproduction in the genetic conservation of rare tree species: The examples of common yew (T. baccata). Forest Snow Landsc Res 2000;75:251-66.

Riedl H. Taxaceae. In: Reichinger KH, editor. Flora Iranica, Lfg No. 12/31:1; 1965.

Sabina PD. Research concerning the production of planting material using vegetative propagation on Taxus baccata $\mathrm{L}$. Bulletin of University of Agricultural Science and Veterinary Medicine-Cluj-King Michaud of Romania. 2006;63:1-2.

Sahni KC. Gymnosperms of India and Adjacent Countries. Dehradun, India: Bishen Singh Mahendra Pal Singh; 1990.

Saini RP. Vegetative Propagation, Silviculture Hills Division. West Bengal: Bulletin No. 11998. p. 1.

Sharma OP. Chai or tea substitutes of wild plants in Jammu woodlands. Medplant ENVIS Newslett Med Plants 2014;7:7.

Singh RR, Chander H. Effect of auxins on rooting behavior of neem (Azadirachta indica) branch cuttings. Indian Forest 2001;9:1019-24.

Thomas P, Farjon A. Taxus wallichiana. IUCN Red List of Threatened Species; 2011, Version 2013.2. Available from: http://www.iucnredlist.org. [Last accessed on 2014 Apr 20].

Troup RS. The Silviculture of Indian Trees. Vol. 3. Oxford: Clarendon Press; 1921. p. 1170-1.

van Hofi E. Rooting Taxus cuttings with no heat. Comb Proc 
Int Plant Propag Soc 1978;28:514-6.

Vance NC, Rudolf PO. Taxaceae, the yew family, Taxus L. In: USDA Forest Service, Seeds of Woody Plants in the United States, Agricultural Hand Book: 450. Washington DC: US Government Printing Office; 1974.

von Korya JP. Propagation of Taxus cuttings. Comb Proc Int Plant Propag Soc 1976;26:1-179.

Wani MC, Taylor HL, Wall ME, Coggon P, McPhail AT. Plant antitumor agents. VI. The isolation and structure of taxol, a novel antileukemic and antitumor agent from Taxus brevifolia. J Am Chem Soc 1971;93:2325-7.

Wheeler NC, Hehnen MT. Taxol: A study in technology commercialization. J Forestry 1993;91:15-8.

Woo DD, Miao SY, Pelayo JC, Woolf AS. Taxol inhibits progression of congenital polycystic kidney disease. Nature 1994;368:750-3. 